Revista de la red interuniversitaria de estudios sobre las literaturas rioplatenses contemporáneas en Francia

15 | 2016

Un año. Literatura argentina 1969

\title{
Cortar, pegar, montar el 69 de Cortázar
}

\section{Joaquín Manzi}

URL: http://journals.openedition.org/lirico/2994

DOI: 10.4000/lirico.2994

ISSN: 2262-8339

Editor

Réseau interuniversitaire d'étude des littératures contemporaines du Río de la Plata

Referencia electrónica

Joaquín Manzi, « Cortar, pegar, montar el 69 de Cortázar », Cuadernos LIRICO [En línea], 15 | 2016,

Puesto en línea el 05 octubre 2016, consultado el 30 abril 2019. URL : http://journals.openedition.org/ lirico/2994; DOI : 10.4000/lirico.2994

Este documento fue generado automáticamente el 30 abril 2019.

\section{(c) $(\mathbb{0} \Theta \Theta$}

Cuadernos LIRICO está distribuido bajo una Licencia Creative Commons Atribución-NoComercialSinDerivar 4.0 Internacional. 


\title{
Cortar, pegar, montar el 69 de Cortázar
}

\author{
Joaquín Manzi
}

1 Es bien sabido que la década del sesenta fue decisiva para Julio Cortázar. Por su intensa actividad creativa, con una docena de publicaciones, entre las cuales tres novelas -Los premios, Rayuela y 62, modelo para armar-, dos contarios -Historias de cronopios y famas, Todos los fuegos el fuego- y dos misceláneas -La vuelta al día en ochenta mundos y Último round- sin contar las reediciones y los libros de artista. También por el reconocimiento editorial y la exposición mediática ligada al boom, que encabezó junto a Gabriel García Márquez y Mario Vargas Llosa. Finalmente por su implicación creciente en asuntos culturales y políticos latinoamericanos luego de la revolución cubana.

2 En su caso, el año mayor de la década, o el de mayor intensidad, es quizás el 68 con su separación de Aurora Bernárdez y el abandono de su casa del décimo quinto distrito parisino y con su participación en la revuelta estudiantil de mayo y en el congreso de Casa de las Américas de La Habana. Pero la tibia acogida a la tercera novela y el trabajo de preparación de la segunda miscelánea arriba mencionadas señalan algo que tan sólo atraviesa ese año, algo que no termina de cuajar entonces y se prolonga quizás hasta el 73 con El libro de Manuel, presentado por el escritor en el Buenos Aires de la primavera camporista. Luego de este último relativo fracaso, los libros siguientes regresan a formatos editoriales y géneros literarios mucho más convencionales.

Estas incertidumbres en cuanto a la década (la del sesenta o la del sesenta y setenta) y su clímax (el segundo volumen de las Cartas va del 64 al 68, el tercero de 69 al 84) señalan quizás algunos de los escollos propios al acercamiento histórico mismo. Trabajar un año y no un texto, un autor o una cuestión- presupone para la crítica literaria el desarrollo de un programa narrativo capaz de justificar el recorte temporal o, por lo menos, menguar su arbitrariedad, privilegiando ciertos órdenes o series de acontecimientos en lugar de otros. Para menguar ese desliz narrativo, quizás valga la pena detenerse en el gesto mismo de separación y ruptura propio al suceder: aquello que adviene, se destaca o separa, recibiendo sentidos y enlaces con otros eventos en una red de mayor amplitud. Dicho de otra manera no habría acontecimiento sin corte. 
4 En el caso de Cortázar, los cortes del 69 -exaltantes, inquietantes, imprevistos- se ubicaron en la bisagra entre lo escrito y lo vivido. Esa bisagra encuentra su forma más acabada en Último round, el libro editado ese año (Bocchino 1996). A diferencia de la estrategia novelística de Rayuela, -desdibujar el corte radical del comienzo (Premat 2013)-, aquí se exponen cortes que conllevan partes iguales de conflictividad, ambiguedad y desencuentro hasta llegar a una desarticulación mayor. Veamos enseguida los gestos principales que subyacen

\section{Cortar y recortar}

5 Último round, publicado en octubre del 69 a cuatro mil ejemplares, expone diversa y repetidamente cortes (reales o figurados) que, además de significantes y violentos, son sobre todo soberanos. Algo que Gilles Deleuze conceptualizó ese mismo año colocando al acontecimiento precisamente en «la punta más contenida, en el filo de una operación» (175). Advenidos en la singularidad del último año de la década que este libro viene a concretar y cerrar a la vez, los cortes hechos allí por Cortázar son escritos, puestos en página junto con imágenes diversas. ¿Cuáles son en concreto?

6 En primer lugar, el libro rompe con La vuelta al día en 80 mundos publicado por Arnaldo Orfila Reynal en la misma editorial Siglo XXI dos años antes. A partir de los libros ilustrados de principios de siglo y de los almanaques de la infancia, Julio Silva había compuesto y diagramado una miscelánea con textos recobrados e imágenes libres de derechos de autor. En el segúndo libro, el amigo Passepartout ${ }^{1}$ de La vuelta al día en 80 mundos dio entonces el golpe de gracia al almanaque, de tono nostálgico, dinámica coleccionista y viajera:

Esta casa está fría y llueve (carajo). Pero le meto duro al libro. Ah, novedad: lo de «Almanaque» salta. No me gusta. Se va a llamar Último round, que juega con «round» de box, o sea vuelta (última vuelta de la pelea - última vuelta al día, ¿ves?) (CortázarSilva 2013: 78).

El proyecto repite la vuelta -al día, en buena compañía- pero para romper definitivamente con ella: es la dinámica de todo comienzo. Gracias al éxito de ventas del primero, el editor brindó medios mayores para realizar el segundo con la impresión en Torino y el pago de las colaboraciones de fotógrafos y artistas contemporáneos como A. Gálvez, J.-M. Folon, P. Alechinsky y A. Seguí entre otros. La variedad de formatos y soportes icónicos, así como la heterogeneidad de textos (poemas, cuentos, ensayos) y tonos (serio, absurdo, paródico) se conectan tanto con la actualidad más inmediata como entre una y otra de las partes del libro: el «Primer piso» (PP) y la «Planta baja» (PB), cada una con diferentes tipografías y tamaños (Bodoni 12 y Arial 10). El nombre de esas secciones aparece relegado a la página 219 y siguientes para acreditar a los autores de las imágenes, dotadas de un rol preponderante en lo que corresponde designar con el nombre de montaje (Didi-Huberman 2009: 76-100).

El libro presenta un paratexto que parodia el formato y la puesta en página de semanarios de difusión masiva como el Selecciones del Reader's Digest (Dávila: 109). En la parte horizontal superior de la portada ocre satinado, un título y un copete; más abajo tres columnas verticales con una decena de recuadros heterogéneos: noticias, avisos, citas y chismes. Entre ellos, la mención zumbona de una condecoración recibida por el escritor, pero también acusaciones muy serias, referidas de modo irónico en el ángulo inferior izquierdo de la contratapa: «LAS GRANDES BIOGRAFÍAS DE NUESTRO TIEMPO: "el escritor Julio 
Cortázar, un pequeño burgués con veleidadades castristas"». A modo de respuesta, una mención entre paréntesis remite a las páginas interiores que reproducen el ensayo «Acerca de la situación del intelectual latinoamericano» (PB: 199-217), ya publicado en Casa de las Américas en 1967. Así, anacrónica y ambiguamente, Último round corta con la prensa masiva sin sustraerse a su vez a diversas disputas protagonizadas por máscaras o personajes del escritor, advenidas en el ruedo mediático ese mismo año y los siguientes.

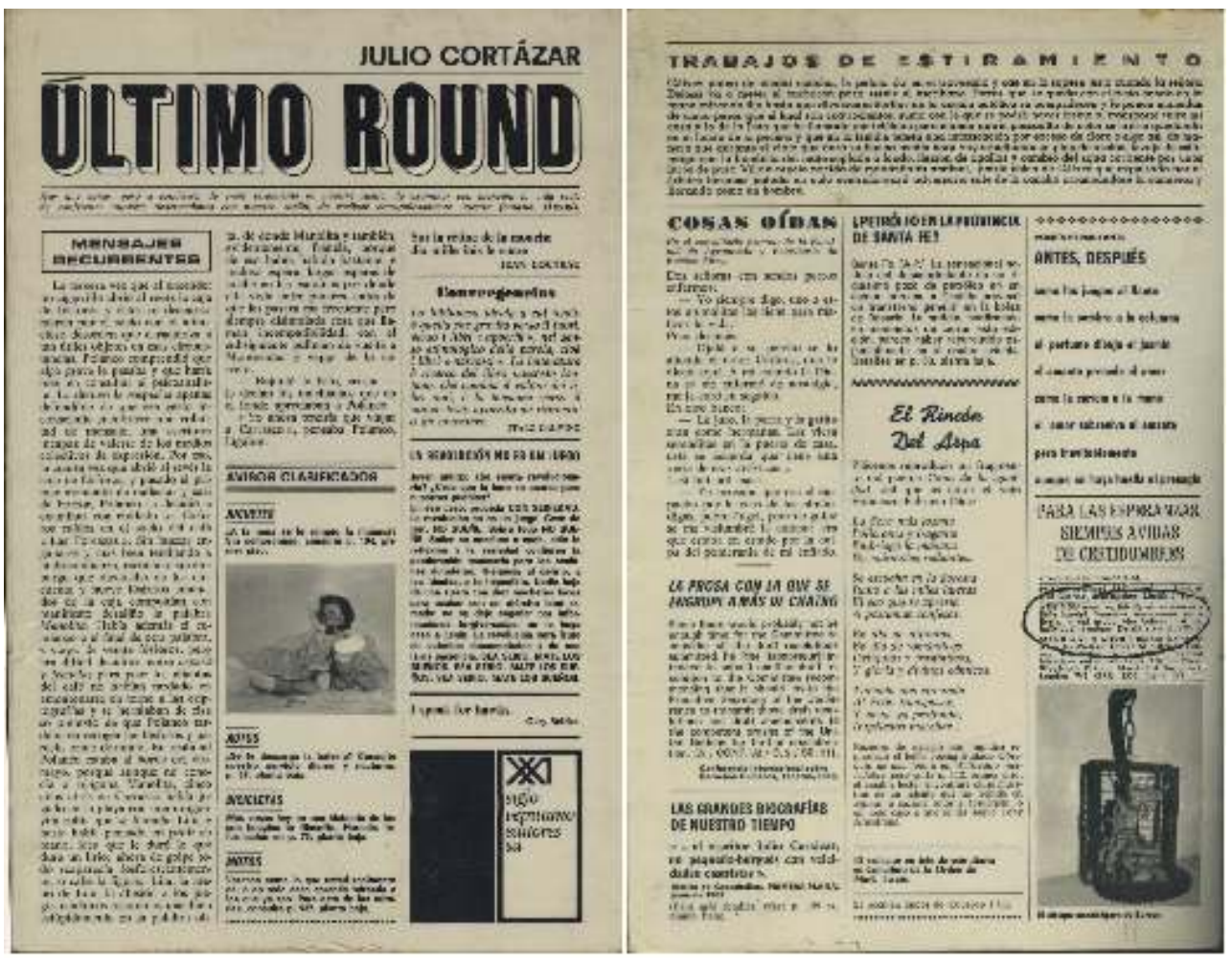

Cubierta y contracubierta. Edición original.

9 A la vista de la portada resaltan los cortes verticales y hortizontales. En el interior del libro, también prevalecen a través de un guillotinado interno y transversal realizado en el tercio horizontal inferior de las páginas a dos columnas: es este otro corte el que permite leerlas de modo irregular y cruzado. Por medio de esas dos partes, el libro del 69 corta entonces dentro de la serie editorial de las misceláneas compuestas con Julio Silva y también en su interior mismo, dando como resultado una percepción fragmentaria del tiempo contemporáneo. Esto permite al lector poder hacer una serie de combinaciones mientras lee, así por ejemplo puede leer en la Planta Alta la página 25, mientras tiene abierta la Planta Baja en la página 57.

10 Esa fragmentación aparece anunciada en la portada con una cita de Cocteau en negrita ubicada en el ángulo superior derecho: «Sur la rétine de la mouche / dix mille fois le sucre». El filtro antepuesto ante los ojos del lector en su acceso a la realidad no es otro que el del periodismo gráfico, ampliamente parodiado. La realidad podría cambiar si la percepción fuera cortada y montada de otras maneras, así como busca realizarlo este libro, tematizándolo por ejemplo en «Un cristal con una rosa dentro» (PB: 98-101).

11 La primera realidad, una de las más recurrentes en todo caso, es el escritor mismo, a través de su reflexión metapoética en «Del cuento breve y sus alrededores» por ejemplo (PP: 35-45), pero también de sus diversas máscaras textuales. Éstas aparecen sujetas a otras implicaciones del corte, las que surgen de la comparación del retrato fotográfico del 
autor reproducido en la página 9, con una copia que se conserva en el fondo Cortázar del Centre de Recherches Latino-Américaines de la Universidad de Poitiers. La foto impresa fue cinetizada por el artista belga Paul Bury; reproduce en blanco y negro el busto del escritor en tres cuartos. El rostro mira a la cámara pero aparece descompuesto en 16 círculos, concéntricos y desplazados. A pesar de girar alrededor del ojo derecho, los cortes circulares no deforman la cabeza, que se mantiene entera.

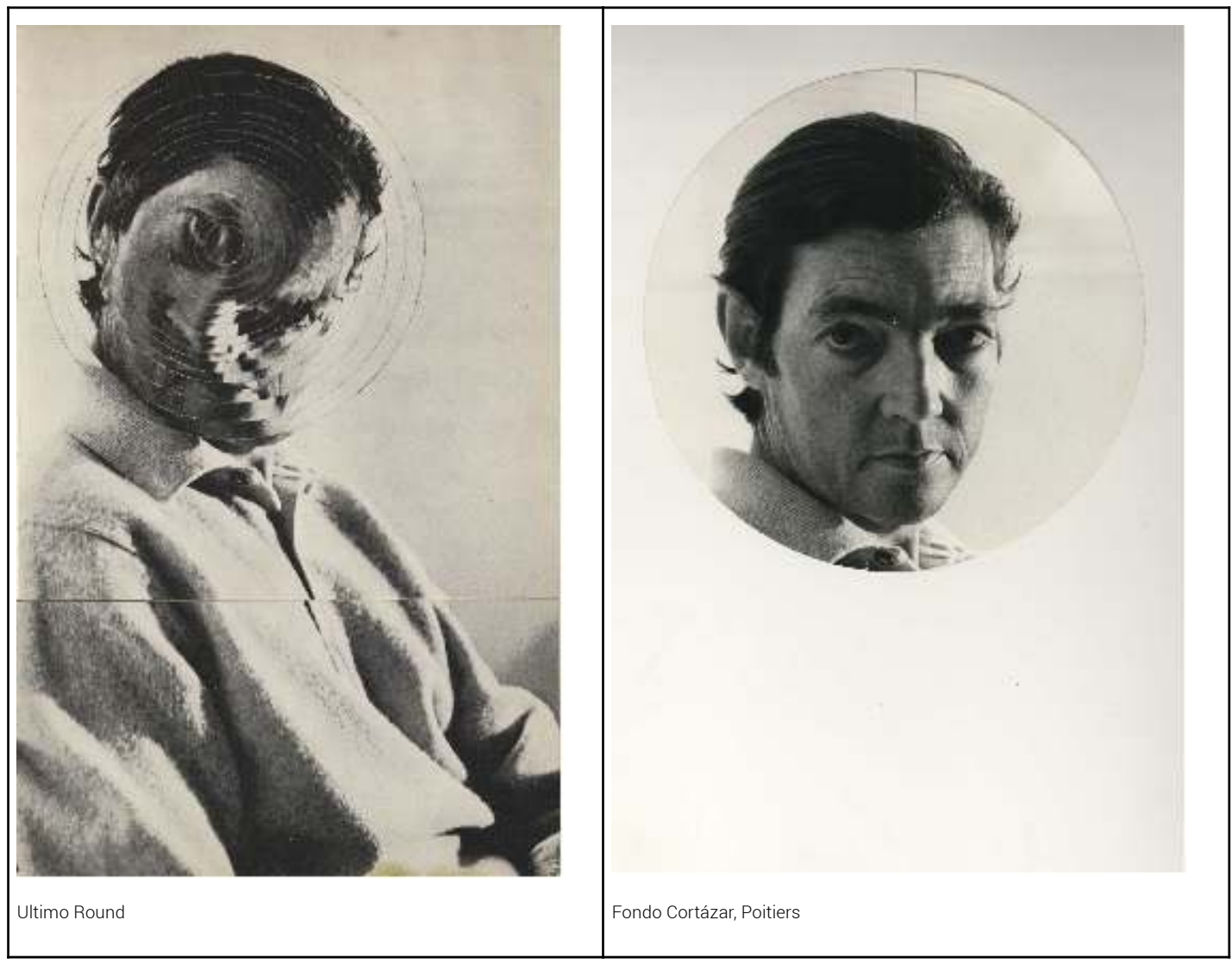

La foto conservada en Poitiers es precisamente la parte central del retrato original revelado y copiado en el estudio fotográfico parisino Roger Pic, que había sido entregado al artista belga por Julio Silva, mientras componía la diagramación del libro con Cortázar. Esa foto es un resto, un desecho del retrato cinetizado publicado: muestra precisamente sólo la cabeza, recortada en forma circular. El rostro a su vez está cortado en dos, longitudinalmente a la altura del ceño; este corte limita precisamente el borde exterior del círculo central y menor de la otra foto.

En el retrato cinetizado, los cortes concéntricos y sus desplazamientos laterales consiguen agrandar el ojo derecho y deformar el rostro del escritor, entonces lampineo. Accesoriamente, cabe recordar que por aquellos años el escritor empezó un tratamiento hormonal para aumentar su pilosidad, lo cual modificó profundamente su rostro. A título de ejemplo, una carta a Mario Vargas Llosa de marzo de 1970 refiere el extrañamiento de un empleado de correos inglés que compara la foto del permiso de residencia en Francia con el rostro que tiene delante suyo (Cortázar 2000: 1385)². Ubicado en el umbral interno, entre el índice y el primer texto y entonces también entre el rostro lampíneo y el barbudo del escritor, el retrato cinetizado expone a la vez que escamotea la imagen autorial 
primera. Así la vuelve evasiva o perdida, dado que además está cortado en su tercio inferior por las dos partes en que se divide.

Ahora bien, reconsiderando los tres cortes a la obra en esa página 9, resalta su carácter singular ya que ninguna otra imagen ocupa los dos pisos. Se trata entonces de una imagen única (no hay otro retrato autorial en todo el libro), pero también colectiva (en su producción participaron Bury y Silva). Cargada de un sentido experimental (debido a la cinetización, claramente expuesta), no excluye sin embargo el anclaje icónico (el busto permanece intacto). Este retrato paradójico de la página 9 encuentra su imagen recíproca en la página 6, que está en blanco frente a los dos índices de la página siguiente, cuyas secciones aparecen separadas por una treintena de rayas negras horizontales.

Como faltan ambos números a pie de página, se puede precisamente pensar lo que pasa entre uno y otro. Del 6 blanco y vacío al 9 lleno, esas páginas dan a pensar gráficamente los dos números finales de la década. El 6 y el 9 son el uno para el otro como la década que se cierra con el 69. Del 6 vacío se salta al 9 opaco pero sobre todo, resistente, expectante. El seis y el nueve son gráficamente invertidos y simétricos, o si se quiere, recíprocos. El 6 y el 9 quedan uno frente a otro, girando sobre sí mismos: combatiendo. Esta podría ser quizás una de las metas del corte: efectuar el cambio brusco de situación, la ruptura entre un elemento y otro.

\section{Abrir y cerrar}

Del mismo modo que Cortázar se expone icónicamente de modo huidizo en el segundo umbral, también las prosas liminares explicitan una posición autorial semejante: evidente pero reacia a las expectativas del público. Al tono sutil y falsamente serio del primero, que sugiere que Yepes, un boxeador, no debería haber vuelto al ring para complacer a sus admiradores de antaño y perder la pelea -«Descripción de un combate, o a buen entendedor» (PP: 13-14)-, el último lo traslada ficcional y cómicamente a esferas artísticas -«A los malos entendedores» (PP 217). Con estos dos textos ficcionales que pasan del ring al escenario, o de la arena circense a la periodística, el escritor refiere su voluntad de rehuir una pelea espectacular, mediatizada. Sin embargo, ya desde el título anuncia también que corre la última vuelta del combate y no habrá otra luego. Vistos los breves reenvíos espiralados creados por estos dos textos ubicados en las antípodas del libro, la contradicción y el conflicto no cesan, puestos en movimiento por las variantes léxicas del paratexto «a buen entendedor» / "A los malos entendedores») y por los hiatos entre las subpartes de un todo fragmentario, entrecortado y vagamente circular.

Así, desde lo fragmentario de cada uno de sus componentes, el espacio textual se expone continuamente abierto (a los otros textos) sin dejar de cerrarse sobre sí mismo poéticamente. «Sílaba viva» (PP: 11), el primer texto, reproducido en tipo mayor y en un único párrafo, es un poema dedicado a otro hueco o falta, nombrada paradójicamente por la presencia futura y actual de un sujeto anónimo. Actualizando la sílaba «che» de manera reiterada, el poema introduce una asonancia constante al final de varias palabras (populares a veces, siempre en minúscula), como si el sujeto en cuestión estuviera con che (Guevara) o fuera lisa y llanamente él como lo sugiere también «Sobremesa» con citas a pie de página del Diario de Bolivia, aunque desprovistas de referencias (PP: 78). Otros muchos textos eligen ese principio elíptico de composición, insistiendo en la ausencia de un elemento textual, el último de cada línea en «Ya no quedan esperanzas de» (PB: 112-124). 
18 Mientras que estos espacios en blanco eliden referentes textuales, otras hendiduras reflotan textos ya editados en revistas y así dan una respuesta alternativa al modo en que el periodismo hacía intervenir en algunas de sus páginas a la literatura de su tiempo (Mudrovcic 1999). Muchas imágenes también ilustran e incluso fingen documentar la prosa ficcional (Dávila: 136); a su vez varios textos pretenden llenar lagunas informativas respecto a la economía mundial (PP: 75), la situación social de la India (PP: 63-74) o la del intelectual latinoamericano, silenciado por «razones de «gorilato mayor» (PB: 199). La planta baja se cierra con la carta a Roberto Fernández Retamar, incluída en el número 45 de la Revista de la Casa de las Américas, punto de partida de un nutrido intercambio con José María Arguedas (Ostria González 2002).

«Casi nadie va a sacarlo de sus casillas» proclama otro de los poemas (PP: 76-77). Sin embargo, durante ese mismo año, el mentado nadie fue encarnado por el peruano primero, luego por David Viñas, desde Madrid (en Cuadernos hispanoamericanos) y también por Óscar Collazos desde Montevideo (en Marcha). En respuesta a esos textos, Cortázar tuvo que argumentar cómo y porqué era posible bregar literariamente en favor de la revolución latinoamericana sin renunciar ni a sus modos literarios híbridos ni tampoco a su modo de vida (parisina, y por eso burguesa para los aprendices de revolucionarios que lo interpelaban públicamente).

El libro del 69 abre un sinfín de huecos para no rescindir el anclaje autorial europeo e internacionalista del escritor. Si los disensos políticos con Mario Vargas Llosa nunca traspasaron la esfera íntima del intercambio epistolar, ni tampoco las diferencias estéticas con Julio Silva empañaron una amistad que se prolongó en otros trabajos a lo largo de la década siguiente, eso fue porque el peruano y el argentino se encontraban en casillas vecinas (londinenses o parisinas), cuando no se instalaban lisa y llanamente en la suya, al sur de Francia como lo relata el diario de «Uno de tantos días de Saignon» (PP: 15-27). Allí diagramaron el libro entre julio y agosto de 1969, y de allí partieron juntos en auto a Torino con el material gráfico, para editarlo e imprimirlo.

21 Allí también diagramaron otros trabajos y pusieron algunos en escena mediante otras vueltas pugilísticas plasmadas en una serie de fotografías en color tomadas por Karine Herriot en las colinas provenzales. El dorso de cada foto lleva comentarios manuscritos en los que anota con humor el knock out en que lo deja el artista en la foto número cinco, a pesar de lo cual el escritor vuelve a posar solo, sin comentario alguno, desafiante y barbudo en la número seis. 


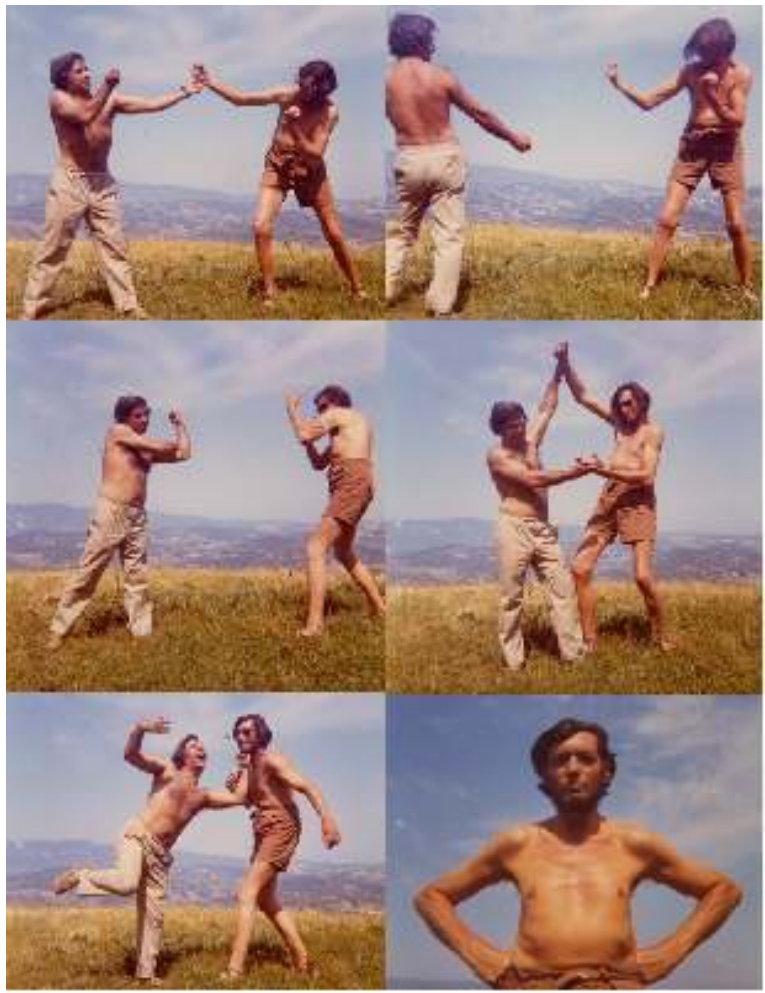

Colección privada

Así como el duelo a cuchillo en Borges, el boxeo pone en juego para Cortázar un modelo masculino atractivo de coraje y elegancia, inalcanzable como no sea a través de la simulación narcisista. Ese modelo agonístico es frecuentemente convocado sin embargo desde la perspectiva distanciada de un espectador (Recabarren en «El fin» de Ficciones), un destinatario (en «Torito» de Final del juego), o un personaje que se mira al espejo y lo refiere literaria e icónicamente. 


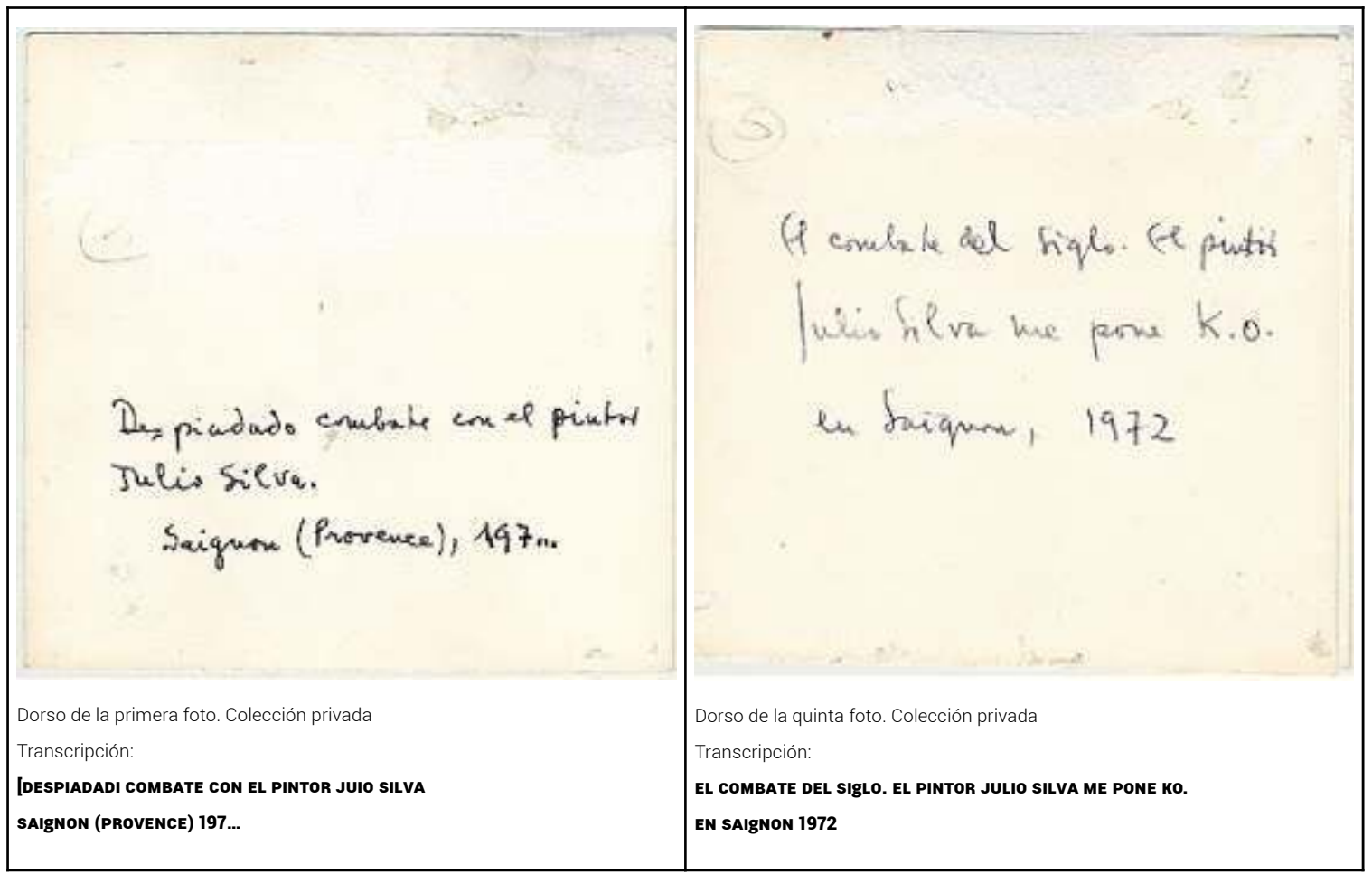

Detrás de todas esta puestas en escena simultáneas (las paratextuales de Ultimo round) o anacrónicas (las fotográficas), emerge con fuerza el sujeto: cortando una pelea, una serie de fotos o un libro. Si bien los cortes dotan al sujeto de unidad (Barthes: 338), delinean también con su profusión una figura textual oscilante, contradictoria y, a la postre, inconsistente tal como surge de su doble llamada al «No te dejes»: ni comprar por los capitalistas, ni vender a formas públicas y espectaculares del compromiso (PB: 125).

24 A fuerza de mantener esta doble negativa en diversos registros discursivos (serio/ ficcional) y en medios radicalmente heterogéneos (periodístico, literario, artístico), Cortázar quedó en entredicho, o distanciado de sus interlocutores. Eso fue lo que ocurrió luego de haber suscrito a la primera carta abierta del 4 de mayo de 1971 a raíz de la detención de Heberto Padilla. Aunque «Policrítica a la hora de los chacales» reafirmara el compromiso con la revolución cubana y también su libertad de tono y de lenguaje (Gilman: 259), el poema no logró zafar del «maniqueísmo» cubano como lo llamaba ya en 1969, aunque sólo en su correspondencia privada (2000: 1338).

\section{Pegar y montar}

Último round abrió espacios de plasticidad mucho más dúctiles y amplios para plasmar parte de lo que ruidosa y pesadamente quiso esclarecer en las diversas polémicas del año 69 y siguientes: su posición respecto a la profesión y la institución literarias. En primer lugar porque se trata de un libro objeto a la Duchamp que funciona a partir de la posibilidad de leer cada parte de modo alterno o asimétrico. De ese modo, con el pasar del tiempo y las lecturas que convocan explícitamente al artista francés (PP: 184-188), los cuadernillos que lo componen se aflojan, se descosen y terminan perdiendo sus páginas dobles, que penden de un hilo y flotan como lo realizaría después y mejor Amalfitano en 
2666 de Roberto Bolaño con el Testamento geométrico de Rafael Diestre (2004: 246). Además, el troquelado de varias secuencias de la Planta baja invita ya a recortar la «Poesía permutante» (PB: 165-172, 184-188, 195-198) ya a disponer los recuadros en un orden distinto al previsto, componiendo poemas en otros soportes.

Lo quiera o no, el lector debe alternativamente deshacer y rehacer el trabajo de composición del libro: volver a pegar imágenes nuevas con páginas viejas y montar ese material tanto en la página como en su conjunto. Este ejercicio de recomposición lectora, Cortázar lo tematiza ingenuamente en «La muñeca rota» ${ }^{3}$ :

Vaya a saber qué curiosos cambios de rumbo puede tener el recuerdo de un libro, su fantasma ya adelgazado, si el autor espera al lector en otra vuelta de la tuerca con una vela encendida en la mano o unas páginas sueltas; su mútua relación, en todo caso, ¿no será más entrañable, no anulará mejor ese hiato hostil entre texto y lector, como el teatro actual lucha por anular el hiato entre escenario y platea? (PP:106).

Al representar el acto de lectura según una dinámica lúdica e incluso amorosa, el escritor simula la encarnación en sus textos, obviando el principio mismo de montaje que sustenta muchos otros después de Rayuela (Césped B. 1972). Así mengua tanto la violencia que supone el corte como la creatividad necesaria para disponer las partes recortadas en figuras nuevas. Sin ir más lejos, debajo de la cita anterior se encuentran tres recuadros de una plancha de contacto fotográfica en blanco y negro en la que vemos una muñeca dada vuelta en una cama, con el calzón progresivamente desplazado. ¿Quién habla ahí, en silencio, y a calzón quitado, en la hendidura abierta entre las dos partes?

Un dúo conflictivo trabajando en silencio y a destiempo. Las fotos ilustran el título de la parte superior pero lo descentran hacia una acción metafóricamente sádica, cargada de referencias surrealistas, a Hans Bellmer en particular. La serie fotográfica realizada con Silva en un hotel parisino asume bien la conflictividad, el agôn que mueve el libro entero y aparece ya en la portada, debajo del título, a modo de advertencia:

Hay que soñar pero a condición de creer seriamente en nuestro sueño, de examinar con atención la vida real, de confrontar nuestras observaciones con nuestro sueño, de realizar escrupulosamente nuestra fantasía. Lenin.

Lema o copete o lema de la publicación, esta cita incluida por Silva vino a suplantar otra de César Vallejo, compasional, deseada por el autor (2013: 84). Luego de su reemplazo, el escritor respondió al diagramador en otro recuadro de la cubierta, incitando absurdamente al lector a que «SEA SERIO. MATE LOS SUEÑOS. SEA SERIO. MATE LOS SUEÑOS».

Para el escritor y el artista, el desliz del sueño a la fantasía creadora capaz de realizarla indica diferencias mayores: móvil y multiforme en un caso, material y concreta en el otro. El diagramador concretó su fantasía en los talleres de Toso, en Torino, según asociaciones anacrónicas de textos e imágenes. El principio que las sustenta, el del montaje, se hace tangible frente a los dos textos dedicados al mayo del 68 francés. 


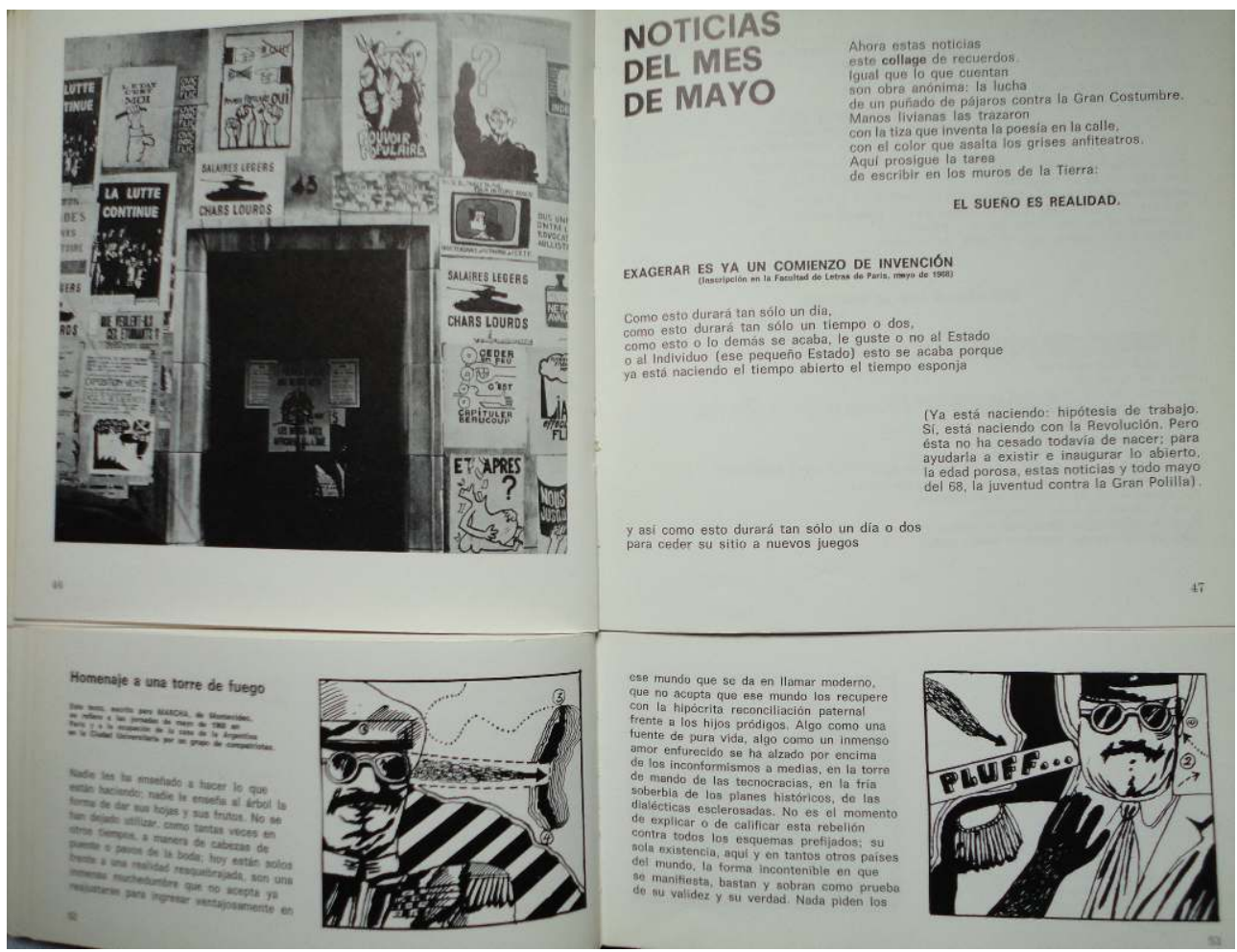

(PP: 46-47) Último round (PB: 52-53)

31 Por un lado, se trata de una evocación lírica de lo sucedido entonces en la Casa Argentina de la Ciudad Universitaria: «Homenaje a una torre de fuego», ya publicado en Marcha, asociado aquí a cuatro dibujos de Antonio Seguí que burlan el imaginario castrense. Por otro, «Noticias del mes de mayo», presenta una sucesión de recuerdos personales puestos en estrofas propias y graffitis ajenos puntuado por cinco fotos documentales de Antonio Gálvez mostrando las paredes cubiertas de afiches y consignas rebeldes. Este largo montaje ubicado en el Primer piso aspira a componer un collage, esto es una imagen única y detenida a partir de diversos fragmentos superpuestos. Sin embargo el poema se desenvuelve hacia un futuro que renueva la revuelta y dialoga a destiempo con las consignas pasadas y las imágenes desacompasadas que van corriendo en las páginas de abajo.

32 Hasta aquí, las imágenes siguen a las palabras. Una sola vez se da el caso inverso, y son las palabras las que acompañan las imágenes, descentrándolas con humor debajo de las fotos de «Diálogo de las formas», suerte de historieta compuesta a partir de fotos sacadas a estatuas de Reinhoud (PP: 165-172). En el resto del libro, las imágenes potencian el componente narrativo de ciertos textos breves armando secuencias icónicas (Chávez: 203). Una treintena de dibujos de Folon muestran en recuadros sucesivos la dimensión semiótica de la docena de prosas heterogéneas para imponerles un signo dramático o irónico. Muchas de esas prosas breves habían sido escritas originariamente en francés y publicadas en $1965^{4}$. Allí donde los grabados en tricromía de Silva descentraban los discursos hacia lo onírico, los dibujos de Folon que acompañan la traducción de esos textos trasladan las fantasías discursivas a espacios despojados y abstractos.

Uno de esos dibujos de Folon es particularmente eficaz, es decir feliz, ya que presenta un paisaje de colinas bajas y rayadas; en una de ellas, se yergue una figura humana de perfil cuya cabeza es una gran tijera. El texto que viene gráficamente a completar (más que 
acompañar), «Se dibuja una estrellita» (PB: 78-79), destila un erotismo turbio que ejerce sobre una página de papel o una piel un agente ambiguo: ora un escritor, ora un sacerodote, ora un cirujano.

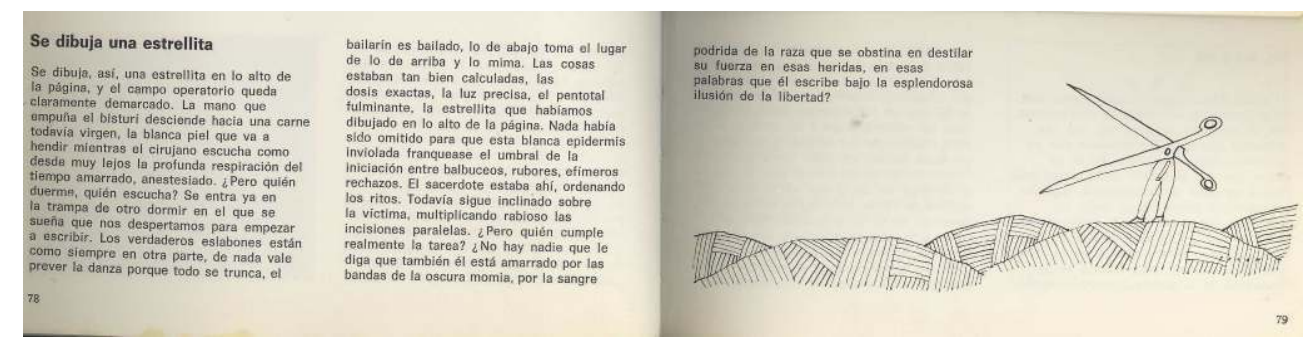

(PB: 78-79)

El erotismo poéticamente sádico de esta tijera se ejercita a lo largo de todo el libro del 69. Lamentablemente fue normalizado hasta desaparecer constructivamente de las reediciones siguientes puesto que suprimeron precisamente los cortes, sea mediante dos tomos de bolsillo, sea mediante uno solo en el que se fundieron partes de las dos misceláneas ${ }^{5}$. Lo que en ellos quedó de aquel erotismo fue su dimensión falocéntrica más evidente (Stabb: 37): poética en «Naufragios en la isla» (PP: 173-183), ensayística en «que sepa abrir la puerta para ir a jugar» (PP: 141-154) y narrativa en «Tu más profunda piel» (PP: 93-96).

En la edición original en cambio, las imágenes ponen en movimiento la mirada hacia lo que queda fuera de campo, tal y como se observa en «Ciclismo en Grignan» (PB: 70-75), y «Cortísimo metraje» (PB: 86-87). En el primero, con el asiento anticuado de una bicicleta sin ruedas del escultor Robert Muller, el diseñador burla la mirada masculina sobre la ciclista adolescente, quien charla con sus amigas y se excita ante él. En el segundo, con el dibujo de Folon se invierte la fantasía del automovilista asesinado por la muchacha que levantó de la ruta haciendo dedo: el animal más peligroso no es la bestia de tiro, o la manada humana que está disfrazada debajo, sino el jinete (o el conductor) y su fornida dentadura.

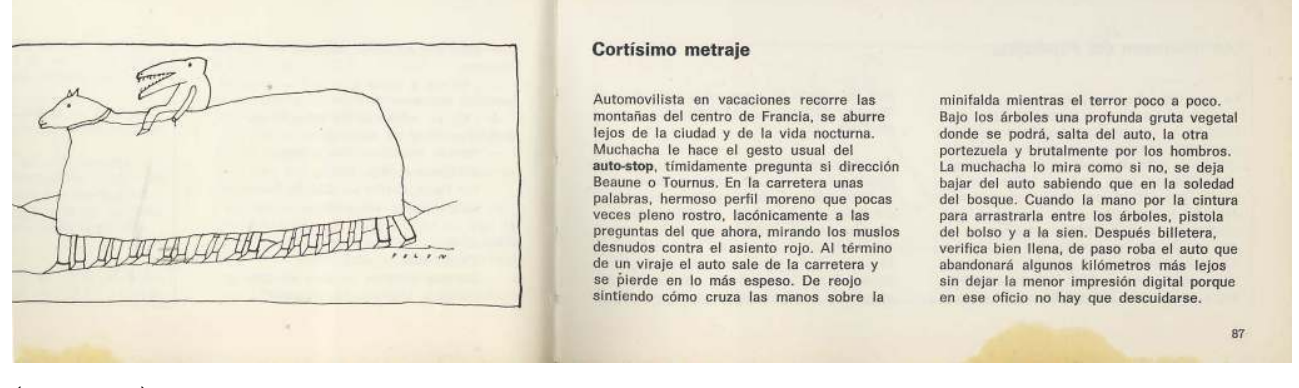

(PB: 86-87)

Las imágenes ejercen un humor oblícuo, capaz de trastocar y descolocar los textos adyacentes. Con el correr de las páginas deforman y desarticulan la fijeza de lo que advino alrededor y fuera del libro hasta hacer girar su materia sobre sí misma, una y otra vez como si el seis fuera el nueve y al revés.

De esta manera, el montaje de Último round pone en manos del lector las posibilidades que el escritor entreveía apenas en su día a día:

esta vida nueva que me he acordado en los próximos diez años útiles que, con alguna esperanza, considero que me quedan antes del sillón de ruedas. Maduro despacito la idea de irme a México el año que viene; de golpe tengo tanta libertad 
entre las manos que casi me da miedo. Y además, la libertad personal afecta casi enseguida la vida y la dicha de los que te rodean: me ha bastado apenas un año para que en torno de mí se tejiera una fina red de problemas ajenos, que, como todo lo ajeno, también es mío (2010: 500).

Este pasaje de la carta a Eduardo Jonquières de agosto del 69 condensa posibilidades y contradicciones vitales que van mucho más allá del tiempo presente y futuro del escritor y se encuentran ya el trabajo y el objeto que tenía entonces en curso. En el montaje de último round los fragmentos textuales propios junto a las imágenes ajenas componen figuras nuevas según una red tenue, móvil, cambiante.

Ninguna otra obra suya llevó tan lejos esta práctica delicada y anacrónica, una de las pocas capaces de poner en crisis el mensaje icónico y textual para ampliar la mirada histórica y también desplazar un compromiso político unidimensional. Como no podía cortar con todo (y en particular con la actualidad argentina, que era incapaz de captar por onda corta en la radio y de comprender siquiera), Cortázar cortó al menos las páginas del libro. Así logró expresar silenciosa y diversamente algo nuevo en lo que acontecía entonces: algo que seguía aún esperando desde un futuro impensado: una herencia libre de testamento, agazapada en cada corte y a cada vuelta de página de su libro más libre.

\section{BIBLIOGRAFÍA}

Barthes, Roland, «Diderot, Brecht, Einsenstein», CEuvres complètes IV. 1972-1976, París: Seuil, 2002, pp. 338-360.

Bocchino, Adriana, «Último round: una bisagra teórica en el desarrollo intelectual de Julio Cortázar», Actual, n³3, 1996, pp. 293-312.

Bolaño, Roberto, 2666, Barcelona: Anagrama, 2004.

Broichhagen, Vera, «Julio Cortázar o las barbas del diablo», Cuadernos LIRICO, $\mathrm{n}^{\circ} 7,2012$. En línea: http://lirico.revues.org/595. Consulta: 05/06/2016.

Césped B., Irma, «El montaje como recurso en Rayuela», Revista Chilena de Literatura, $\mathrm{n}^{\circ}$ 5/6, 1972, pp. 111-132.

Chávez, Marisol Luna, La vuelta al día y Último round de Julio Cortázar, Universidad de Guadalajara, 2014.

Cortázar, Julio, Ultimo round, México: Siglo XXI, 1969, 220 p.

Cartas 1, 2, 3, edición de A. Bernárdez, Buenos Aires: Alfaguara, 2000.

---- Cartas a los Jonquières, Madrid: Alfaguara, 2010.

_-_-- y Silva, Julio, El último combate, Barcelona: RM, 2013.

Dávila, María de Lourdes, Desembarcos en el papel. La imagen en la literatura de Julio Cortázar, Rosario: Beatriz Viterbo Editora, 2001.

Deleuze, Gilles, Logique du sens, París: Minuit, 1969. 
Didi-Huberman, Georges, Quand les images prennent position, París: Minuit, 2009.

Gilman, Claudia, Entre la pluma y el fusil: debates y dilemas del escritor revolucionario en América Latina, Buenos Aires: Siglo XXI, 2012.

Mudrovcic, María Eugenia, «El arma periodística y una literatura "necesaria"», Historia crítica de la literatura argentina, vol. 10, Cella, Susana (éd.), Buenos Aires: Emecé, 1999, pp. 295-312.

Ostria González, Mauricio, «Sobre árboles y pájaros: la polémica Arguedas/Cortázar», La licorne $\mathrm{n}^{\circ}$ 60, 2002, pp. 341-354.

Premat, Julio, «Dar el salto. Los comienzos de Rayuela», Cuadernos LIRICO nº 9, 2013. En línea: http://lirico.revues.org/1157. Consulta: 05/06/2016.

Stabb, Michael, «Not text but texture: Cortázar and the new essay», Hispanic review, n 52, 1984, pp. 19-38.

\section{NOTAS}

1. En francés, passe-partout es la llave que puede abrir todas las cerraduras y también el soporte de cartón que permite enmarcar una imagen. Con su práctica de diagramador, Silva proporcionó a Cortázar la ganzúa para sacar de la caja fuerte algunos de sus inéditos y también el espacio idóneo para darlos a leer junto a un sinfín de imágenes (2013: 139-152).

2. Signo corporal de un cambio político, la barba es otro mito biográfico cortazariano, debidamente alimentado por él mismo (Broichhagen 2013).

3. Fue reproducido en otro formato por la revista Los Libros en el número 5 de noviembre de 1969. 4. Les discours du Pince Gueule fue editado en París por Jean-Michel Cassé; era una edicion de artista de cien ejemplares con grabados originales. En 2002 Fata Morgana reeditó el libro reproduciendo algunos de ellos.

5. Respectivamente México: Siglo XXI, 1972 y París: Gallimard, 1982.

\section{RESÚMENES}

A través del estudio pormenorizado de los componentes paratextuales, discursivos e icónicos de Último round, se abordan aquí algunos de los dilemas que Julio Cortázar afrontó en el último año de la década del sesenta.

L'étude détaillée des aspects discursifs, paratextuels et iconiques de Último round, permet d'aborder quelques-uns des principaux dilemmes vécus par Julio Cortázar au cours de l'année 1969.

Analysing some aspects of Último round, this paper focus on main conflicts experienced by Julio Cortázar all along the last year of the sixties. 
ÍNDICE

Mots-clés: coupure, Cortázar, image, livre, montage.

Keywords: Julio Cortázar, book, editing.

Palabras claves: corte, imagen, libro, montaje.

\section{AUTOR}

\section{JOAQUÍN MANZI}

Université de Paris-Sorbonne

joaquinmanzi@gmail.com 